\title{
Cadastral Information and Erosion Modeling for Monitoring Gullies in Mpazi Catchment Area, Kigali City
}

\author{
Bizimana, J. P. ${ }^{1}$, Ndahigwa, E. ${ }^{2}$ \\ 1. University of Rwanda, College of Science and Technology, Department of Geography and \\ Urban Planning; and Centre for Geographic Information System and Remote Sensing, \\ Nyarugenge Campus, P.O. Box 3900 Rwanda.
}

2. Ministry of Environment, Rwanda Land Management and Use Authority, Department of Land Administration Cadastral Maintenance Unit; Kigali, Rwanda.

Correspondence: Bizimana Jean Pierre, Email: bizijp@yahoo.fr

\begin{abstract}
Due to the lack of sediment load monitoring system, erosion model calibration is challenging in Rwanda. Based on the reports of parcels boundaries corrections from Rwanda Land Management and Use Authority, there are quite consistent losses of land due to gullies development in Mpazi River watershed. This study analysed the possibility of integrating cadastral information, erosion and hydrological modelling data for identifying potential gullies development in hilly urban area of Mpazi catchment. The orthophoto of 2008 coupled with ancillary data were used to delineate the shifts of parcel boundaries from 2012 to 2016. Hydrological modelling based on DEM was also applied to investigate geo-physical characteristics and potential gullies. The differential GPS was used to locate the potential gullies that were then uploaded into GIS. Gullies intersecting with rectified parcels boundary were measured with tape meter. The gully length was measured using hydrological modelling tools and GPS coordinates captured during the field verification. The results showed that gully system expanded from 7.5 to 20 meters while neighboring parcels shift was between 3 and 12.5 meters. The highest average rate of soil loss ranged between 100 and 150 tons/ha/year. The research findings from this study are salient for policy- and decisionmakers who need to review the current land and environment policies and laws so that gully erosion can be assigned appropriate mitigation measures for ecologically sustainable management of hilly urban landscapes within Kigali City. More periodic data are required to feed the model and validating this approach brings the government institutions' responsibility. The developed methodology has the potential to quantify the gully systems in urban context with scarce hydrological, soil and geomorphological data availability and where urban planning and environmental protection are constrained by limited financial and human resources.
\end{abstract}

Keywords: Cadastral Maintenance Data, Erosion Modelling, Gully, Urban Areas

\section{Introduction}

Gully is relatively permanent steep-sided water course that experiences ephemeral flows during rainstorms. Compared with stable river channel, gullies are characterized by a head cut and various steps or knick-points along their course (Morgan, 2009). The incision of channels may be instigated by surface wash, land sliding, or pipe failure (Knighton 2014). Most research dealing with soil erosion by water has concentrated on sheet (interrill) and rill erosion processes operating at the (runoff) plot scale. Relatively few studies have been conducted on gully erosion 
which represents an important fraction of sediments source in river systems and at larger spatial scales (Poesen et al. 2003; Capra et al. 2005; Poesen et al. 2010). Gullies have been recognized as most severe environmental threat in highly populated areas with high rainfall intensity especially in hilly urban areas where they accelerate sediment transfer as well as water quality deterioration (Ionita 2006). The issue of urban erosion has been hot topic of geo-morphologists such as Matthew \& Aderemi (2013) who stressed that preventing gullies is more efficient and effective than treating the impact of gullies.

Land degradation in Rwanda was given a priority in strategic plan for sustainable land use and management. For instance, the strategic plan for land sub-sector in Rwanda seeks to ensure sustainable and rational land use through a comprehensive national land use master plan; guarantee security of land tenure for all land claimants through systematic land tenure regularization; and strengthen land administration through capacitating land structure (Government of Rwanda 2010a). According to Garadi \& Twesigye (2005) and Tsinda \& Gakuba (2010), irrational use of land in Rwanda negatively impacts on land fragmentation and scattered settlements. High intensity rainfall, overflow of the river banks and change in hydrological processes are dominantly responsible for runoff, floods and ravines. Many researchers stressed that the increase of impervious areas as results of urbanization alters the hydrologic response of a watershed by increasing the hydraulic efficiency of the area and similarly reducing the infiltration and surface storage of rainfall and increases surface water runoff and soil erosion (Moeyersons 1991). The rapid and unplanned urbanization of Kigali City in Mpazi catchment modified the catchment hydrology, and thus accelerating gully erosion and causing serious damage to urban structures like roads, bridges and buildings. Increased impervious surfaces lead to large, rapid increases in surface runoff in urban catchments during storm events, in addition to changes in the upslope contributing area due to rerouting of urban runoff that can exacerbate erosion (Junior et al. 2010). Road building is known to disturb the equilibrium of catchment hydrology (Nyssen et al. 2002) and to generate by far most runoff and, therefore, are considered as the primary reason for gullying (Imwangana et al. 2014).

The consequence of gully erosion in hilly urban area of Mpazi catchment is alarming (Karlsson \& Viklander 2008; Munyaneza et al. 2013) with heavy financial losses in vicinity of gullies along with water quality deterioration (Government of Rwanda 2013). Existing reports about the parcels boundaries corrections at Rwanda Land Management and Use Authority (RLMUA) indicate the consistent land losses mainly due to gullies development especially during the rainy seasons. Moreover, several studies conducted in Rwanda have evidenced the impact of human activities and road construction on accelerated gully erosion especially on very steep slopes (Moeyersons 1988; Moeyersons 1991; Moeyersons 2003). The present study attempted therefore to analyse the gully development and its driving factors in hilly urban area of Mpazi watershed by using cadastral maintenance data and erosion modelling. Identification of major gullies was based on topographic, cadastral maintenance data, land cover and land use data to estimate gullies development rates and to calibrate erosion model. The main causes of gullies development have been assessed and preventive and control measures to reduce the (gully) erosion in Mpazi catchment have been recommended.

Many researchers applied the Revised Universal Soil Loss Equation (RUSLE) at different spatial scales (Renard et al. 1997) and in different settings including Rwanda (Karamage et al. 2016a; Karamage et al. 2016b). While RUSLE model is good for modelling sheet, rill and interill erosion, it does not account for deposition processes and channel erosion such gully erosion (Miller et al. 2003). Thus, RUSLE based soil modelling approach was simply selected to estimate the erosion rates and potential gullies. This information was then overlaid with the result 
of the hydrological modelling by using DEM in order to identify the potential gullies in Mpazi sub-catchment. It has also been combined with cadastral maintenance data to quantify the soil erosion loss in order to plan for gully erosion control and management. However, cadastral maintenance data used in this study was limited to parcels intersecting directly with the major gullies. The temporal scope of the study is limited to five years' period (2012-2016) corresponding to the systematic Land Tenure Regularization (LTR) and availability of cadastral maintenance data in Rwanda. Even if gully system in the study area was developed many decades ago, tools to monitor its development were not in place. The cadastral database would be therefore a benchmark for gully development assessment in hill urban areas. This study will raise awareness of policy-makers on sustainable urban planning that takes into account the urbanization impact on gullies creation on hilly urban areas.

\section{Material and Methods}

\subsection{Setting the Scene}

A cadastre is a public data inventory concerning properties based on a survey of their boundaries. The comprehensive cadastre commonly includes details of the ownership, the tenure, the precise location, the dimensions (area), the use, and the value of individual parcels of land (Henssen \& Williamson 1990). Such properties are identified by means of some separate designation (Henssen 1995). Regarding parcel boundaries, the reliable data play an imperative role. The accurate position of the boundary within these physical features depends on the "general" land law of each country known as a "general boundary system". The system provides, however, for the precise surveyed boundaries to be "fixed" if desired by the land owners (Henssen 1995). The land administration system in Rwanda is based on a reformed cadastral system, including land mapping, recording of all land-related data and land titles (Government of Rwanda 2012c). The Rwandan Land Tenure system is similar to the Torrens System which was developed in Australia and further applied over the world (Whalan 1982). The Torrens System has based on three main principles: (i) mirror principle where the register reflects accurately and completely the current state of the legal situation; (ii) curtain principle where no further investigation beyond the register is required apart from overriding interests; and (ii) insurance or guarantee principle where the state recognizes that what is recorded is true for third parties in good faith and that a bona fide rightful claimant who is contradicted by the register is reimbursed from an insurance fund of the state (Henssen 1995).

Rwanda has been implanting a LTR program since 2005 with trials till 2008 and full implementation in 2008 (Government of Rwanda 2012c). This program intended to provide all rightful landholders a legal and a valid land title documents in order to minimize land related disputes. In this programme, the general boundaries demarcation marked on orthophoto or enlarged satellite images was used. The claims were assessed in the field through a highly participatory system involving all land owners. Although LTR has been a success, the critical challenge is maintain the system in terms of the information on parcels and right owners that is regularly changing due to different types of transaction on land such as sale, inheritance, subdivision/merge of parcels, servitudes, expropriation, corrections (Whalan 1982). The aforesaid exercise is named as Land Administration Information Systems (LAIS) or cadastral maintenance. 
It is a GIS-based land information management linked to the system of land tenure regularization where GIS activities are carried and communicated into LAIS.

The land law determining the use and management of land in Rwanda states that all lands had to be formally registered (Government of Rwanda 2005b). In this land registration process, participatory mapping was adopted for field data collection using plotted orthophoto for parcel boundaries demarcation and registration for recording related legal administrative attributes (Rugema Milindi 2011). Prior to the participatory demarcation of buildings and parcels boundary from orthophotos, the used high resolution satellite imagery and aerial photos have been geometrically corrected and orthorectified using ground control points to build a correlation between the image pixels in 2-D image space and their ground locations in 3-D object space (Gianinetto 2009). The maintenance of Rwanda cadastral data passes through a set of activities namely sporadic registration, subdivision, merging, boundary change, and field verification (Government of Rwanda 2012c). Currently, some land owners in Mpazi catchment are applying for boundary correction since their land was washed away by soil erosion. The exercise of correcting those parcels' boundaries is in line of adopting mirror principle that governs land registration in Rwanda. The update of cadastral maintenance data has a strong relationship with spatial change that occurred. Cadastral maintenance data differs from urban dynamism to environment threat such as gully system development. After the systematic land registration, maintenance of geo-database commenced as a backbone of spatial transaction. This is depicted through the Mpazi catchment area where rectification of parcels boundary after few years of systematic land registration shows how gully system develops. On very steep slopes, the parcels are washed away by gully erosion. In lower laying areas and wetlands, parcels are covered by sediment loads from uphill of the Mpazi catchment as result of the flash floods (Bizimana \& Schilling 2010; Mureithi 2015).

\subsection{Study area}

Mpazi catchment is one of sub-catchment of Nyabugogo catchments that lies between $1^{\circ}$ $56{ }^{\prime} 15^{\prime}$ 'S and $1^{\circ} 58^{\prime} 45^{\prime}$ 'S with $30^{\circ} 02^{\prime} 00^{\prime} \mathrm{E}$ and $30^{\circ} 03^{\prime} 45^{\prime \prime} \mathrm{E}$. This sub-catchment has an area of 888.90 ha and it is located in western part of Kigali City, Nyarugenge District. Figure 1 shows the location of Mpazi catchment in Kigali City. 


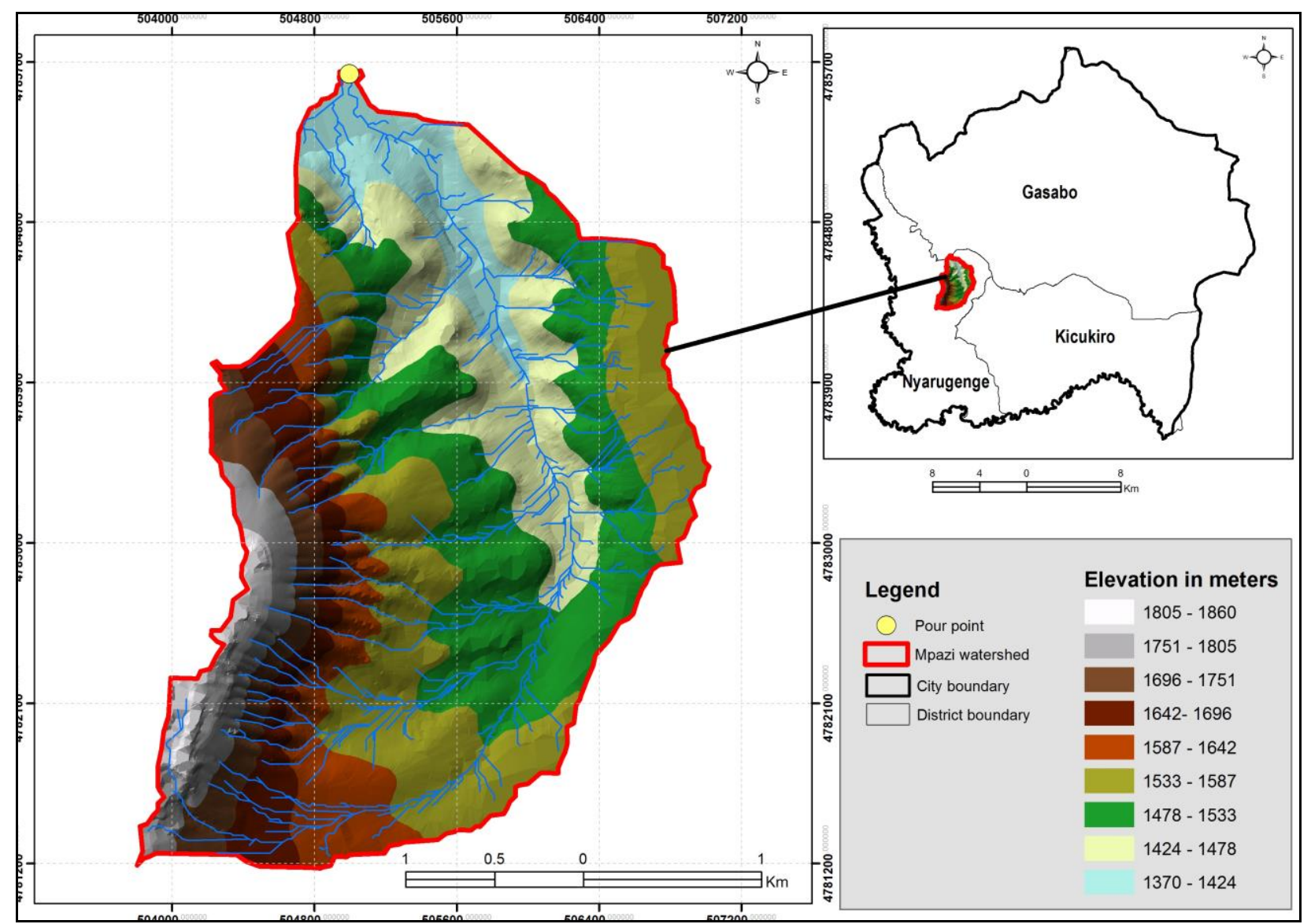

Figure 1: Location of Mpazi Catchment in Kigali City

According to the 2013 Kigali Master Plan, the topography of Mpazi catchment is characterized by gentle slopes on the shelves but quickly become very strong on hillsides and very steep when approaching the high and low areas (City of Kigali 2010). Mpazi sub-catchment discharges the Mount Kigali flow in the South through the commercial hub of Nyabugogo and contributes high amount of water in Nyabugogo River. This is influenced by the degraded steep slopes in the water heads of Mount Kigali, dense unplanned settlements in Kimisagara, Nyakabanda, Cyahafi and Muhima areas, clogged culverts and bridges that impede the flow of water in Mpazi channel (Manyifika \& Rientjes 2015). The densely urbanized Mpazi watershed is also accelerating the narrow outflow of the Mpazi River in downstream (Nyabugogo Commercial Area is the cause of localized flash floods (Bizimana \& Schilling 2010; Mureithi 2015). 


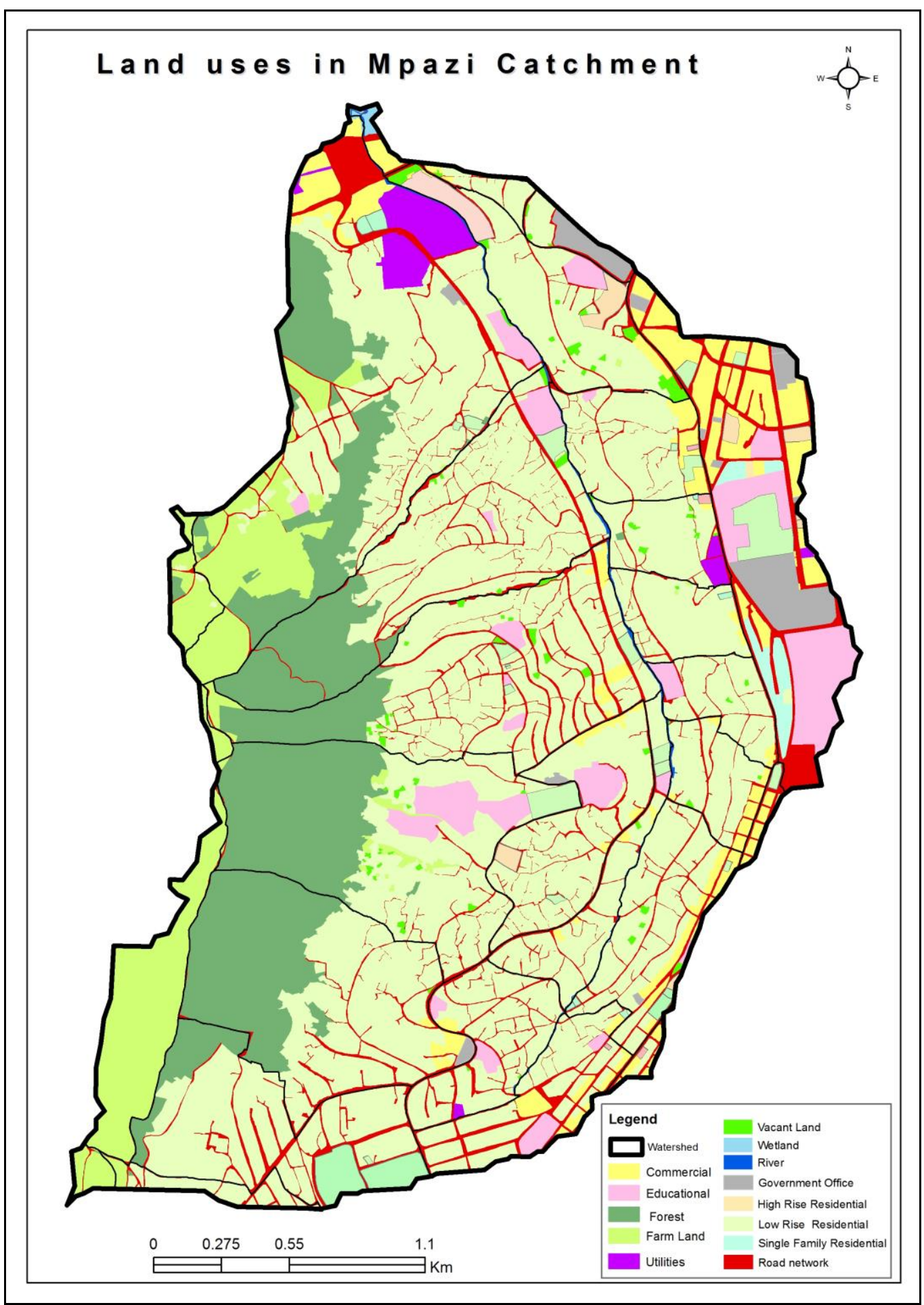

Figure 2: Land uses in Mpazi catchment

Figure 2 shows the main land uses within Mpazi catchment area. The average annual temperature in Mpazi catchment ranges between $16^{\circ} \mathrm{C}$ and $20^{\circ} \mathrm{C}$. The climate is characterized by two rainy seasons that generally occur from February to May and from Mid-September to Mid-December with an annual average rainfall ranging between 1,250 and 1,300 millimetres. The geological structure of Mpazi catchment area comprises the meta-sedimentary and granitic rocks such as schist, sandstones, and siltstones. Lateritic soils, rich in iron and aluminium cover the hillside surfaces, while alluvial and organic soils are found in lowlands and wetlands (Mureithi 2015). 


\subsection{Data acquisition}

Secondary data were collected from different publications accessed from governmental institutions and electronic resources. Primary data were collected by field observation and measurements. The gullies in Mpazi catchment were firstly located using two methods. First, the orthophotos of 2008 that were used during SLR coupled with vector data vectorized. The hydrological modeling by using Digital Elevation Model (DEM) was then performed for delineating potential gullies that was later verified with a field reconnaissance. The gully polyline features were then uploaded into GPS equipped with upgraded ArcPad mobile GIS (Version 10.6). The gullies intersecting with rectified parcels boundary during the period of 2012 to 2016 were assessed with tape meter to get the width of gullies while the gully length was calculated in GIS. The main purpose was to know how gully development is mirrored from parcels boundary rectification. Hence, for calibrating the model, the field data coupled with the secondary data were brought together.

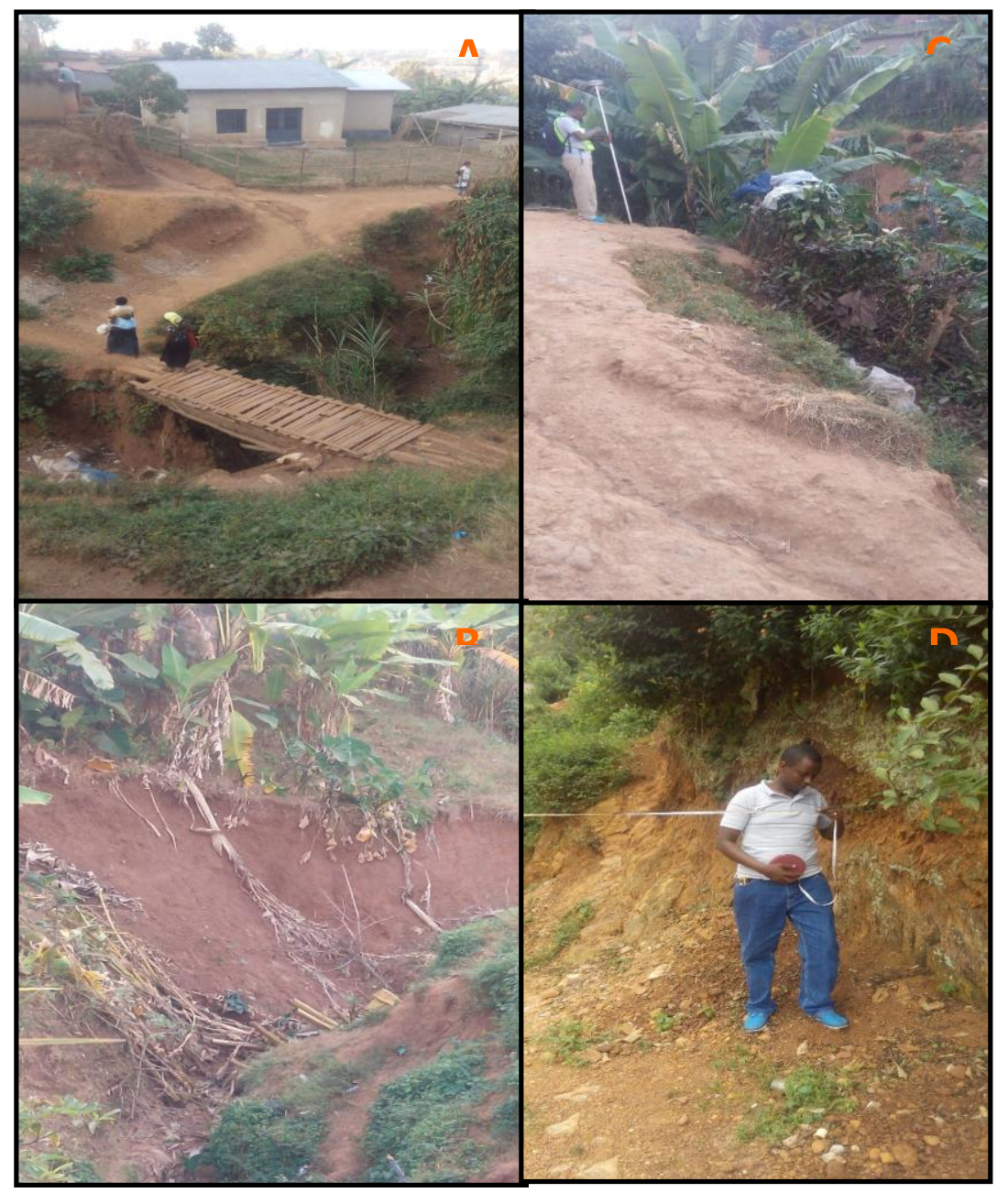

Figure 3: Gully development during fieldwork

Figure 3 presents gully development and field measurements; photo $\mathbf{A}$ is showing how threatening is gully within studied area, photo $\mathbf{B}$ shows how gully is eating up parcels, photo $\mathbf{C}$ is presenting a use of GPS tablet to delineate gully development, and photo D shows field measurement with tape meter. 


\subsection{Data processing}

Mpazi gully system was delineated using the DEM of 10 meters. The first step involved burningin existing stream network and filling the existing sinks in DEM. After DEM conditioning, the derived topographic input data sets to further step of hydrological modelling including depressionless DEM, flow direction, and flow accumulation (Jenson \& Domingue 1988; Seibert \& McGlynn 2007; Pilesjö \& Hasan 2014).

\subsection{Data modelling and analys is}

\section{Hydrological Modelling}

The map algebra tool was useful to create a new raster layer containing only those pixels, which have an accumulation value bigger than a fixed threshold. With this stream network, it was able to calculate: different segments for the network using spatial analyst tools of stream to feature (Jenson \& Domingue 1988). For the extracted streams, later gully flow was assumed based on stream order, for all the other pixel sheet. With the threshold set to 100 accumulated pixels corresponding to a drainage area of about 888 hectares. As the true expression is 1, all pixel values with an accumulation bigger than 100 was assigned 1, all others pixels 0 to better locate even rills in the catchment. Mpazi catchment has got many gullies classified according to their segment length adapted to created stream order for identifying and classifying water streams based on their numbers of tributaries (Strahler 1957; Tarboton et al. 1991).

\section{Soil erosion modelling}

The modelling of soil erosion rate was drawn on RUSLE developed by Renard et al (1997) for estimating soil erosion rate at rive catchment scale level. RUSLE is expressed by A=R.K.L.S.C.P; Where: A is an average annual soil loss; R represents the Rainfall/ Erosivity as the power of rainfall to erode the soil resulting from the energy of falling raindrops; LS as topographic factors of slope length $\mathbf{L}$ and the Steepness $\mathbf{S}$; $\mathbf{K}$ as soil Erodibility as the measure of the vulnerability of soil to erosion which is influenced of the physical characteristics of the soil; $\mathrm{C}$ denotes the crop management is the ratio of soil loss under a given crop to that of bare soil; and $\mathbf{P}$ as the support practice factor which compares the soil loss from cultivated land without conservation practice to that with conservation practice (Onyando et al. 2005).

* Rainfall erosivity: Rowntree (1982) suggested the Fournier Index as the most effective method for estimating local erosivity in tropical catchments than conventional methods based on maximum rainfall intensity. The Fournier Index is calculated as follow: $\boldsymbol{F}=\frac{\mathbf{p} 2}{\mathbf{P}}$; where: $\mathbf{F}$ represents the Fournier Index value; $\mathbf{p}$ is equal to total rainfall in the wettest month in $\mathrm{mm}$, and $\mathbf{P}$ representing annual precipitation in millimetres. Since the network of weather stations that are recording the rainfall is still sparse in Rwanda, extrapolation of pluviometric data was based on remotely sensed monthly/annual rainfall. The erosivity was thus extracted from Rwanda soil data properties which portray that $\mathrm{R}$ factor of Mpazi catchment is $1100 \mathrm{MJ} \mathrm{mm}$ $\mathrm{ha}^{-1} \mathrm{~h}^{-1}$ year ${ }^{-1}$ after investigating the spatial distribution of rainfall erosivity in Mpazi catchment (UNEP 2011). 
* Slope Length and Steepness: the output of slope length and steepness Map was recommended by Morgan and Davidson (1991) in estimation of soil erosion. Slope length is the horizontal distance from the origin of overland flow to the point at which either the slope gradient decreases sufficiently to result in deposition or the runoff water enters a channel. Consequently, the soil loss per unit area increases as the slope length also increases. The slope steepness is the segment usually expressed in percentage (Goldman et al. 1986). For a single plot of land, slope length is determined by visual inspection of the erosion process (Lal 1988). For Mpazi catchment, the steepness and slope length focused on determining slope gradient (Johnston \& MacCoy 2001), and assuming that the effects of slope steepness have a greater impact on soil loss than slope length. The steeper the slope, the greater is the erosion (Ganasri \& Ramesh 2016).

* Soil erodibility: soil erodibility refers to how susceptible is the soil particles to be detached and transported by rainfall. It reflects the rate of erosion per unit erosion index from a standard plot and its value ranges from 0.02 to 0.69 (Mitchell et al. 1980; Park et al. 1980). The average rate of soil loss in Rwanda in response to specific rainfall erosivity (soil erodibility) has been measured directly by soil scientists (Kabirigi et al. 2017; Nyesheja et al. 2019). The relative soil erodibility estimates for Rwanda was then used to create a GIS layer showing that the soil erodibirity into Mpazi catchment varies between 0.10 and 0.19 (UNEP 2011).

* Land cover management (C Factor): The C factor depends on vegetation's cover percentage and growth stage. The land cover management factor was defined by Wischmeier \& Smith (1978) as the ratio of soil loss from land cropped under specific conditions to the corresponding loss from clean-tilled, continuous fallow. The effect of mulch cover, crop residues and tillage operations should also be accounted for in $\mathrm{C}$-factor. The mulch cover, crop residues and tillage operations should also be accounted for in the C-factor. Based on the studies by Kim et al. (2005), and Ganasri \& Ramesh (2016), C factor of 0, 0.003, 0.09 and 0.63 were assigned to wetland and bare soils, forest, settlement and grassland, and croplands respectively. According to a study by Karamage et al. (2016b), the highest value of the $\mathrm{P}$ factor (0.75) was assigned to croplands, which are responsible for nearly $95.8 \%$ of total annual soil loss in Rwanda.

Table 1: C factor Values of Mpazi Catchment

\begin{tabular}{clc}
\hline No & Land cover classes & C factor \\
\hline $\mathbf{1}$ & Agriculture & 0.75 \\
$\mathbf{3}$ & Built up area & 0.09 \\
$\mathbf{4}$ & Roads & 0.09 \\
$\mathbf{5}$ & Forest & 0.03 \\
$\mathbf{6}$ & Bare soil & 0.0 \\
$\mathbf{7}$ & Water body & 0.0 \\
\hline
\end{tabular}

- Conservation practices (P factor): $\mathrm{P}$ factor characterizes the ratio of soil loss by land management practice to that of straight-row farming up and down the slope (Devatha et al. 2015). P factor takes into account the control practices that reduce the erosion potential of the runoff by influencing the drainage patterns, runoff concentration, runoff velocity, and 
hydraulic forces exerted by runoff on soil. The value of $\mathrm{P}$ factor ranges from 0 to 1 , where the value closer to 0 indicates good conservation practice while the value near to 1 indicates poor conservation practice (Ganasri \& Ramesh 2016). Land cover in Mpazi catchment has been changing over time as it is depicted through Google imagery this brought on board the complexity of assigning $\mathrm{p}$ factor into catchment. Therefore, conservation practices factor was found through literature review. Due to the lack of field data regarding the conservation practices that have been taken in place, $\mathrm{P}$ Factor values used in this study were generated based on previous studies such as UNEP (2011), Karamage et al. (2016a) and Bizoza \& De Graaff (2012) which showed that the conservation practices are still immature in Rwanda. Normally, the extraction of $\mathrm{P}$ factor values is based on slope gradient and support practices such as terracing and tillage for soil conservation (Kim et al. 2005; Panagos et al. 2015a; Panagos et al. 2015b). Other studies showed that ploughing, planting and cultivation on contours, strip cropping, and terracing and subsurface drainage influencing soil erosion by modifying the flow pattern, grade or direction of the surface runoff and by decreasing the amount and rate of runoff. With this regards the $\mathrm{P}$ factor values have been acquired from a desk review of published works and assigned to land cover classes and different land uses. For instance Devatha et al. (2015) assigned a $\mathrm{P}$ factor value of 0.4 to agricultural land, 1 to built-up land, 0.1 to tree covered area, 1 to waste land and a value of 0.5 to water bodies. Drawn on these previous works, we assigned the $\mathrm{P}$ factor values to different land cover classes found in Mpazi catchment area (Table 2).

Table 2: $\mathrm{P}$ factor values of Mpazi catchment

\begin{tabular}{clc}
\hline No & Land Cover class & P factor \\
\hline $\mathbf{1}$ & Agriculture & 0.4 \\
$\mathbf{3}$ & Built up area & 1.00 \\
$\mathbf{4}$ & Roads & 0.8 \\
$\mathbf{5}$ & Forest & 0.1 \\
$\mathbf{6}$ & Bare soil & 0.45 \\
$\mathbf{7}$ & Water body & 0.50 \\
\hline
\end{tabular}

Source: MINAGRI, 2014 and compilation by authors, 2016

The highest values of $\mathrm{P}$ factor were assigned to roads, built-up areas and bare soils that are characterized by poor conservation practices. As highlighted by Renard et al (1997), poor land management practices increase the erosion potential from runoff by its influence on drainage patterns, runoff concentration and velocity, and hydraulic forces. The low values of $\mathrm{P}$ factor were assigned to forests and croplands that are supposed to reduce the soil erosion.

\section{Results and discussions}

\subsection{Gullies and Rills in Mpazi Catchment}

Starting from the DEM, hydrologic features of the topography like flow direction, flow accumulation, flow length, stream network, and drainage areas were extracted (Jenson \& Domingue 1988). By using the GIS function of flow direction, a single downstream cell, in the direction of the steepest descent was defined for each cell to allow a unique connection from each cell to the watershed outlet to be computed (O'Callaghan \& Mark 1984). This process produced a cell network that represents the paths of the watershed flow system (Mark 1988) 
mainly seen as gullies and rills systems. The total area flowing into a given outlet (a pour point) was delineated based on DEM. Hydrological modelling result shows that gullies and rills systems are mostly located in the high densely populated area of Mpazi catchment. This catchment has got many gullies classified according to their segment length adapted to created stream order (Strahler 1957; Gleyzer et al. 2004).

Mpazi gully system through hydrological analysis was able to identify 488 potential gullies as depicted by feature polylines. By auditing a created gully attribute table, it was found that 249 gullies that have length between 10 to $100 \mathrm{~m}, 131$ gullies are of over 100 meters to 200 meters, 55 gullies over 200 to 300 meters and 53 gullies over 300 meters. Figure 5 shows the predicted gullies and rills in Mpazi catchment. Figure 4 shows the modelled potential gullies in Mpazi catchment area. 


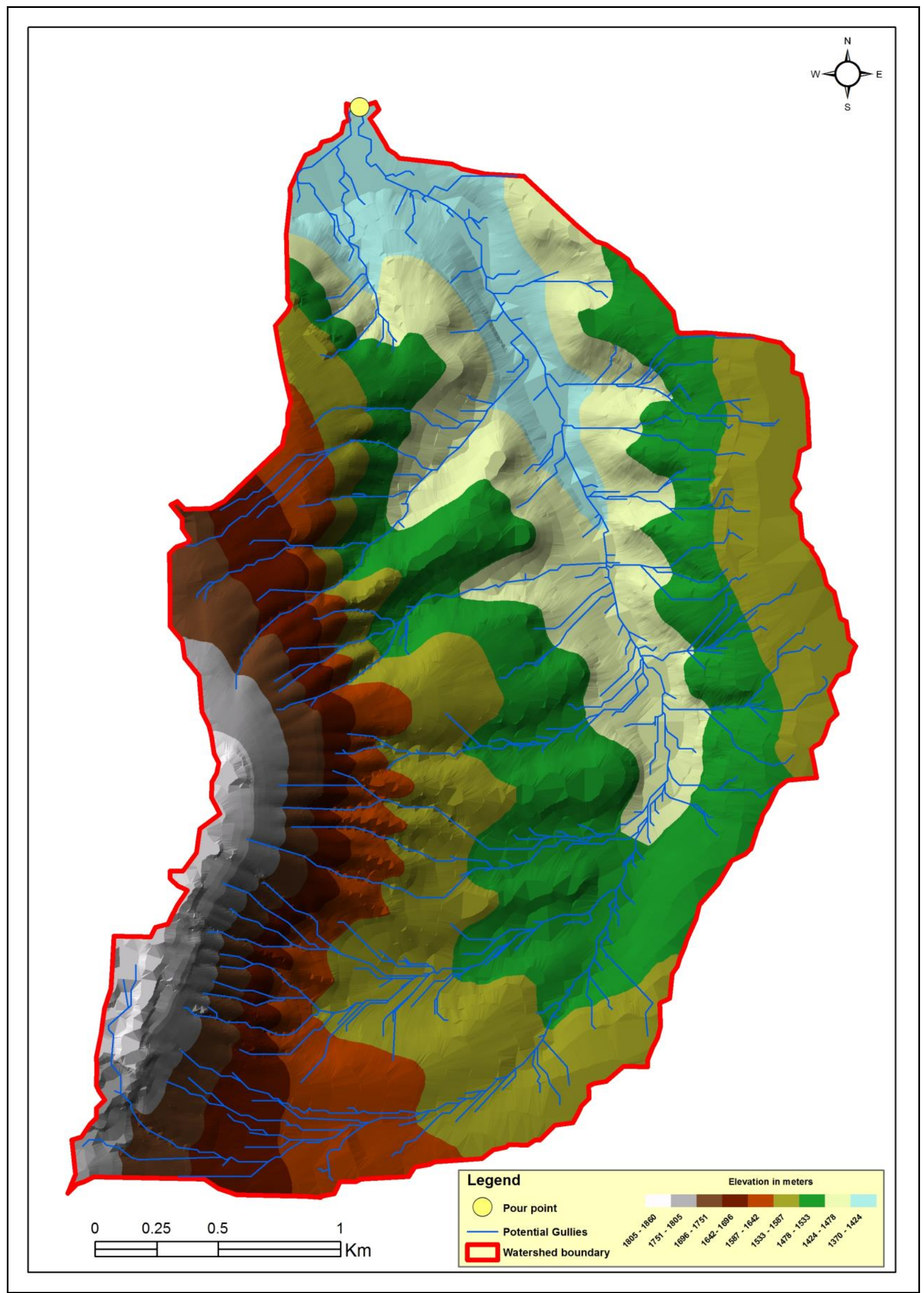

Figure 4: Potential Gullies and rills predicted in Mpazi catchment 
The low rise residential is the dominant land use in the study area. The human settlements are mainly characterized by slums and informal settlements on very steep slopes.

\subsection{Factors of Soil Erosion in Mpazi catchment}

The rainfall erosivity was found to be no variation while interpolating, it remains with only $1100 \mathrm{~mm}$ per year. Consequently, it was not parameterized into soil modeling. On the other hand, the topography (lend of slopes and steepness) of Mpazi river catchment is very heterogeneous. The slope value change greatly from Nyabugogo to Mount Kigali with $4.5 \mathrm{~km}$ of catchment length there is 300 meters of elevation. This is due to the steepness of topography of the area. However, the following sectors Kimisagara, Nyakabanda and Gitega are the ones of highest value of slope factor (Figure 8A). The study shows that Mpazi catchment is heavily urbanized and with steep slopes that is causing the recurrent and very dangerous flash floods that enter and flood the bus station. The upper part of the Mpazi catchment is mostly steep and rocky ground with sparse vegetation; the retention capacity in this part of the catchment is very low (SHERIngénieurs-Conseils 2013).

The soil erodibility (K-factor) is an estimate of the ability of soil to resist erosion based on the physical characteristics of each soil. It is an indicator of the susceptibility of soil particles to detachment and transport by rainfall and runoff (Wischmeier \& Mannering 1969). Mpazi catchment has got 6 classification ranked from number 1 to 4 . It is obvious that all along Mpazi river is of highest rank this was linked to the river bank erosion and it is also due to the land use as stated by Mugisha (2015) that Mpazi has classified into 6 land uses reflecting Manning' coefficient where a value of 0.025 was assigned road, 0.03 to rivers, 0.032 to commercial zone, 0.035 to residential, 0.04 to agriculture and the value of assigned to building footprint. The central part of the catchment has moderated value as the slope is decreasing. The uphill erodibility is low since all remaining natural area like the biggest forest of Kibisogi village in Kigali Cell, followed by forest of Karudandi village of Munira II cell and forest of Munini Village in Nyakabanda I cell.

Cover management (C Factor) is the proportion of soil loss from land maintained under specified conditions to the corresponding loss from continuous tilled bare fallow (Rowlands 2019). The value of $\mathrm{C}$ factor varies from 0 for a well-protected land to 1.5 for finely tilled ridged surfaces that yield much runoff, making more susceptible to rill erosion (Van der Kinijff et al. 2000). The cover management interrelated to the land use since the lowest value coincides with the area that is highly urbanized meaning the cover management is well taken into consideration in fringe zone of Mpazi catchment where natural areas prevail on steep slopes of Mount Kigali. This is can reflected by rectangular patterns for the cover management (C-Factor) in Figure 5. These patterns correspond to the areas covered by forest and woodlands on very steep slopes. 


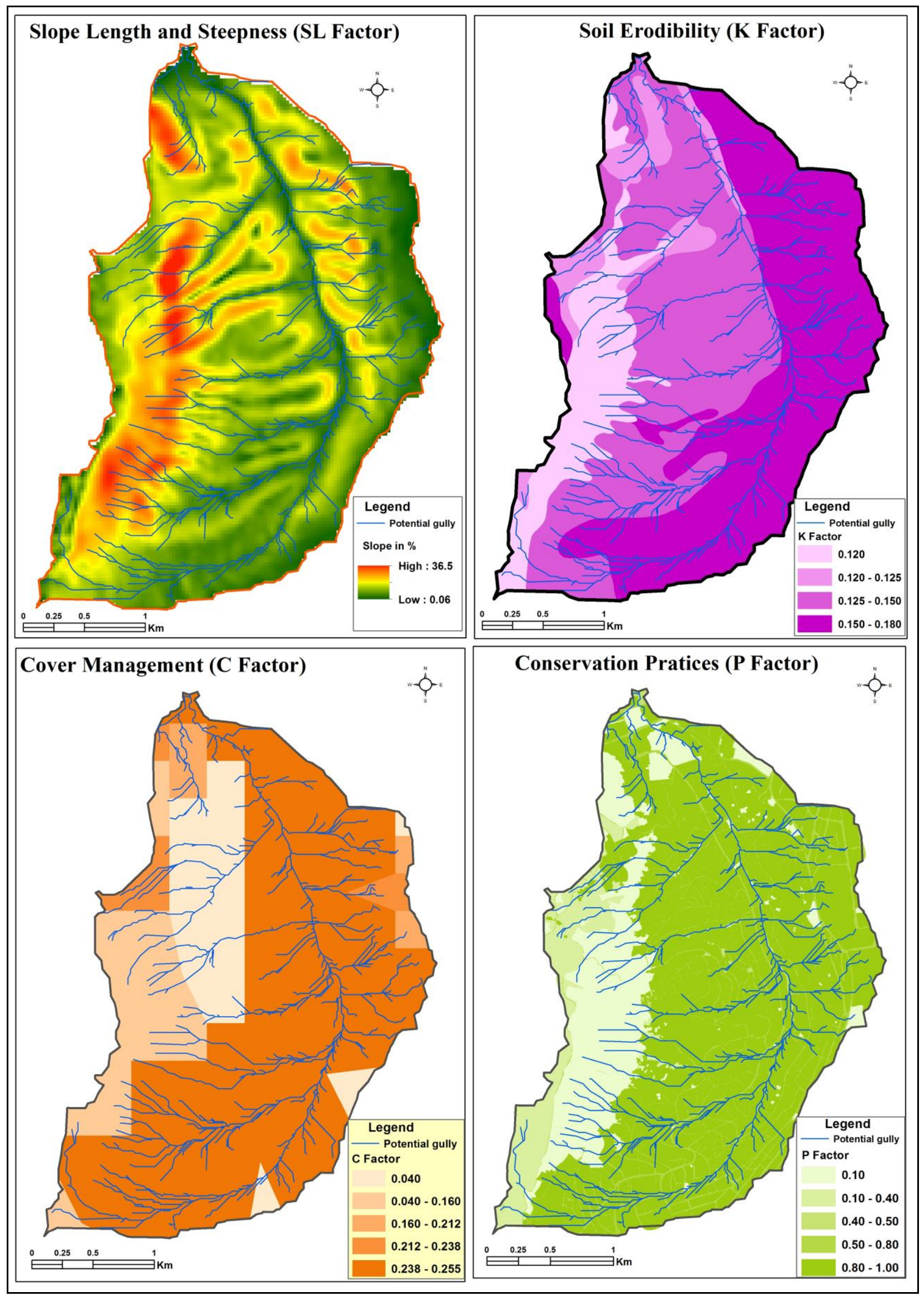

Figure 5: Factors of soil erosion in Mpazi catchment 
The literature reveals that $\mathrm{P}$ factor is interrelated to cover management factor since the support practice is the soil loss incurred when ploughing up and down the slope (Renard et al. 1997). When the land is ploughed on slope directly, $\mathrm{P}$ value is equal to 1 . This is also known as the worst practice. When the adopted conservation practice reduces soil erosion, the $\mathrm{P}$ value is lower and less than 1. The results show that support practice factor is quasi inexistent due the pace of urbanization. The increase of value is associated to some urban dwellers that are adopting septic tanks as water harvesting. In Mpazi catchment, the scattered pattern of settlements intersects with fields arranged on hills in scattered plots, and thus making rational farming difficult and nonprofitable to the urban vicinity.

\subsection{Output of Soil Erosion Model in Mpazi Catchment}

Considering the range of the procedure, the topographic modelling for soil erosion estimation differs in terms of complexity, processes and data required for model computation and calibration, which can be empirical, physical and conceptual (Oliveira et al. 2013). The application of RUSLE model resulted into map showing annual soil loss and soil erosion rate throughout Mpazi catchment. The results reveal that 100-150 tons/ha and per year is the highest average rate of soil erosion. This highest value of soil erosion matches to the high densely populated area of gully system into Mpazi catchment. 


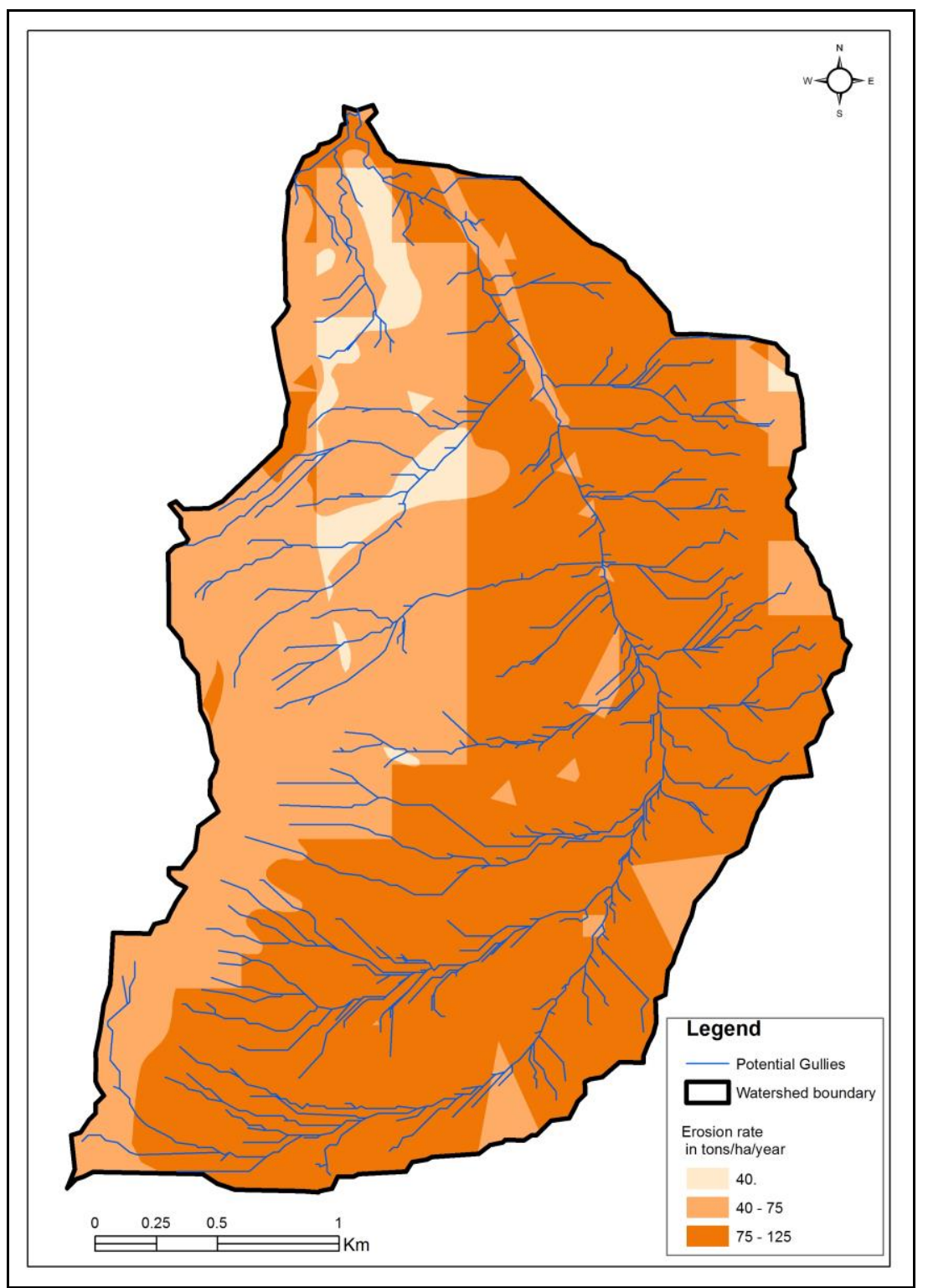

Figure 6: Soil erosion rate in Mpazi catchment

The medium erosion rate is between 50 to100 tons/ha and per year and this rate goes with the encroachment of vegetation cover found into this catchment, it is also the start of runoff creation and rills formation as it is observed from field reconnaissance. Whereas the low erosion rate lies between 30 to 50 and it corresponds to the area that is less urbanized of the catchment.

\subsection{Cadastral Data in Mpazi Catchment}

\section{Cadastral Data with Adminis trative Boundary}

Mpazi gully system drains 26 cells from 8 sectors of Nyarugenge District; it covers also 13,745 parcels as depicted by cadastral database of Lands and Mapping Department of Rwanda Natural resources authority. The size of parcel into studied catchment differs according to land cover and land use types. The cadastral data was overlaid to administrative boundary to highlight overland flow of the created gully system. 


\section{Cadastral Data Intersecting with Gully Network}

Mpazi catchment has got a big gully system where more than 2,246 parcels are under process of being washed away by gully system. Among 2,246 parcels that are under threat of being washed away by gullies development, the data from RLMUA shows that currently in Mpazi catchment area, 35 parcels have undergone boundary rectification. This type of boundary change is exclusively to the ones of gully development intersecting with parcels. Today claimants are applying for area correction that goes in hand with the reduction of land taxes. The map in Figure 6 shows the location of the parcels with the changing boundary and parcels that are intersecting with gullies system in Mpazi catchment area.

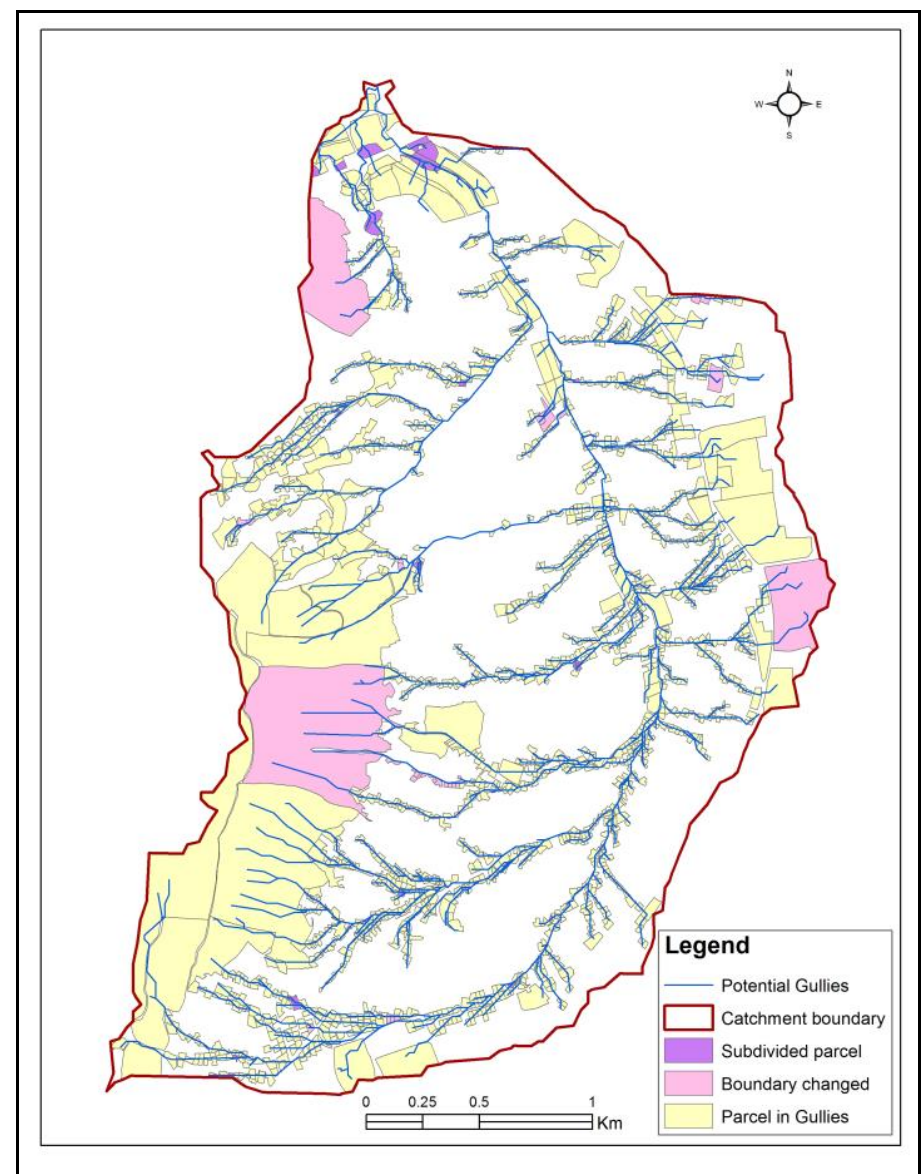

Figure 7: Parcels boundary rectification and gully network in Mpazi catchment area

The surveyed 35 parcels that underwent boundary rectification showed that the range of gully expansion was between 3 to 7.5 meters within the period of 2013 to 2016, this is because all claimants applied in different time. However, it is obvious that there is a link to the soil erosion rate predicted by our model as mentioned on soil erosion rate map.

\section{Gully System and Erosion Rate}

The role of using cadastral maintenance data was to assess gully the development into Mpazi catchment. It is clear that cadastral data was acquired with high precision devices to reflect the mirror principle that governing the Land Registration in Rwanda (Rugema Milindi 2011). The gully expansion was monitored through cadastral data of SLR as initial phase, then the 
rectification of boundary during LAIS maintenance as another milestone of land degradation monitoring. The field measurement to get idea of the development of main gullies showed that the demarcated parcel during SLR washed away by gully erosion. Gully expanded from 7.5 to 20 meters' width to the surveyed parcel ID 1026. Complementary, soil erosion modeling result reveals that 100-150 tons/ha and per year is the highest rate of soil erosion into Mpazi catchment which corresponds to the high densely populated area of a gully system. Thus, this research reveals that there is an overlapping of high soil erosion rate and gully expansion and parcel boundary change and rectification.

\section{Gully System and Parcels Boundary Change}

The mapping report of LAIS maintenance shows that parcels crossing the gully system $\mathrm{t}$ are 2,246 parcels, 35 of them has undergone boundary rectification because of gully development, 36 parcels undergone the land subdivision and one parcel only was for merging for the period of 2012 to 2016. According to land use planning training module of Rwanda natural resources authority, 2014, the implication was fond into anthropogenic factor. Mpazi catchment has inherited to customary occupancy that was not regulated. This situation led to intensive land fragmentation and parcelling, development of settlements on unsuitable areas for agriculture, deforestation and abandonment of fields by indigent owners. The rational use and management of land resources should comply with the master plans, land use plans and zoning regulations, which distinguish different categories of permissible land uses (Government of Rwanda 2012b).

The Ministerial Order $\mathrm{N}^{\circ} 14 / 11.30$ of 21/12/2010 determines the models of land consolidation and its productivity. It also specifies procedures and modalities of land use consolidation for agricultural purposes (Government of Rwanda 2010c). Based on this order, it is prohibited to subdivide the agricultural land if such subdivision is likely to lead to parcels of land of less than one hectare. The land owners shall use the land in accordance with the existing laws. According to the National Land Use Master Plan (Government of Rwanda 2011), mountainous and hilly landscapes very prone to soil erosion should be protected. Nearly $90 \%$ of Mpazi catchment are classified under the category of moderate to high erosion risk soils because they have slopes between $13 \%$ and $55 \%$.

Table 3: Erosion by Category in Mpazi Catchment

\begin{tabular}{cc}
\hline Number of parcels & Slope \% \\
\hline $\mathbf{9 8 3}$ & Over 40 \\
$\mathbf{1 7 9 6}$ & $30-40 \%$ \\
$\mathbf{1 4 4 2}$ & $20-30 \%$ \\
$\mathbf{6 5 4}$ & $10-20 \%$ \\
$\mathbf{5 1 0}$ & $0-10 \%$ \\
\hline
\end{tabular}

The study by RNRA (2013) shows that Mpazi catchment is heavily urbanized while more than $70 \%$ of its soils strongly contribute to gully development. Informal settlement is among the key factors leading to gully development into Mpazi catchment (Government of Rwanda 2012c). Informal settlements result from the policy gaps in land use planning and management to address the community needs. They are physically characterized by concentrated urban neighbourhoods 
lacking proper planning, basic infrastructure servicing, and open spaces; and mainly located on high risk zones (Government of Rwanda 2015).The consequences of informal settlements on gully development are numerous including dumping waste into gully system that leads to poor sanitation and poor drainage (Munyaneza et al. 2013).

\subsection{Policy Implication of Gully Development and Cadastral Data Maintenance}

The erosion rate coupled with parcels boundary rectification into Mpazi River system is linked to the missing provision in laws of buffer to gully system and landslides as it is for other environmental protected area. The buffer zones are areas adjacent to protected or environmentally sensitive areas, on which land use is partially restricted to give an added value of protection to those areas from outside disturbance while providing valued benefits to neighboring rural communities (Wells et al. 1992). Instead of referring to restrictions, some protected areas emphasize the type of activities that are permitted and other activities that should not be allowed in specific areas (Brandon \& Wells 1992; Martino 2001).

The law determines the modalities for protection, conservation and promotion of environment in Rwanda (Government of Rwanda 2005a) is supported by Ministerial Order $\mathrm{N}^{\circ} 007 / 16.01$ (Government of Rwanda 2010b) to establish the buffer zones according to each category of state land including swamp or marshland, river, lake, national park, natural forest, railway and roads. In contrast to aforementioned, hilly urban lands such as of Mpazi catchment can belong either to private individual lands or to the state lands. This land tenure system complicates the protection of areas hilly urban lands from outside disturbance or urban encroachment. The planning of land use and development law in Rwanda stipulates that all lands shall be used according to the provided local plans (Government of Rwanda 2012a). Nevertheless, these physical plans are not in place in different locations of urban area (including Mpazi catchment), resulting therefore in informal settlement proliferation on uphill of Mpazi catchment which accelerates the erosion and gullies development.

\section{Conclusion}

The hydrological modelling into Mpazi catchment revealed 488 gullies potential gullies as depicted by feature polylines. Gully expansion was monitored through cadastral data of SLR as initial phase, then the rectification of boundary during LAIS maintenance. The fieldwork helped to measure the same parcel in order to get idea of gully development. The landscape characterized by high mountains and hills with very steep slopes is a major root cause for soil erosion in the study area. In fact, $90 \%$ of Mpazi catchment fall under the high risk erosion categories. Another factor that lead to gully development is the proliferation of informal settlement which have developed without legal claims to the land or building permit from the concerned authorities

The results show that the highest rate of soil erosion in Mpazi catchment ranges between 100 and 150 tons/ha and per year. This corresponds to the areas where gully expanded from 7.5 to 20 meters next to a high densely populated area of gully system into the catchment. The medium average erosion rate varies between 50 to 100 tons/ha and per year, and this rate goes with the encroachment of vegetation cover found into this catchment. This area also corresponds to the 
starting point of runoff creation and rills formation as it is validated from field reconnaissance. Whereas the low values of soil erosion rate lie between 30 to 50 tons/ha and per year; it corresponds to the area that is less urbanized of the catchment. There is also an overlap of the high value of soil erosion rate and gully development from cadastral maintenance data because gully is much more expanding where soil loss was modelled too high. The erosion rate coupled with parcels boundary rectification into Mpazi system reveals some policy gaps to be addressed through provision in laws of buffer to gully system and landslides as it is for other environmentally sensitive areas in Rwanda. The land use of adjacent to gullies systems and on very steep slopes should be protected for sustainable management of hilly urban landscapes in Rwanda. Based on these research findings, Kigali City is recommended to prioritize Mpazi catchment during Kigali Master Plan implementation so as to timely decelerate and outweigh the issue of informal settlement that lead to gully system development. The urbanization effect on hydrological cycle and gullies development in Mpazi catchment could be shortened by structural mitigation measures such urban greening and runoff water detention in urban drainage systems. The used methodology has the potential to quantify the gully systems in urban context with scarce hydrological, soil and geomorphological data availability and where urban planning and environmental protection are constrained by limited financial and human resources. This research can be extrapolated to other places of urban area that have cadastral data. Hence, the needs of periodic data are required to be collected by government institutions.

\section{References}

Bizimana, J.P. \& Schilling, M. (2010). Geo-Information Technology for Infrastructural Flood Risk Analysis in Unplanned Settlements: a case study of informal settlement flood risk in the Nyabugogo flood plain, Kigali City, Rwanda. In: Geospatial Techniques in Urban Hazard and Disaster Analysis (eds. Showalter, PS \& Lu, Y). Springer Netherlands Doredrecht Heiderberg London New York, pp. 99-124.

Bizoza, A. \& De Graaff, J. (2012). Financial cost-benefit analysis of bench terraces in Rwanda. Land degradation \& development, 23, 103-115.

Brandon, K.E. \& Wells, M. (1992). Planning for people and parks: design dilemmas. World Development, 20, 557-570.

Capra, A., Mazzara, L. \& Scicolone, B. (2005). Application of the EGEM model to predict ephemeral gully erosion in Sicily, Italy. Catena, 59, 133-146.

City of Kigali (2010). Kigali City Sub-areas Planning: Detailed Master Plan Report for Nyarugenge District, February, 2010.

Devatha, C., Deshpande, V. \& Renukaprasad, M. (2015). Estimation of soil loss using USLE model for Kulhan Watershed, Chattisgarh-A case study. Aquatic Procedia, 4, 1429-1436.

Ganasri, B. \& Ramesh, H. (2016). Assessment of soil erosion by RUSLE model using remote sensing and GIS-A case study of Nethravathi Basin. Geoscience Frontiers, 7, 953-961.

Garadi, A. \& Twesigye, B.C. (2005). Pilot Project on Poverty-Environment Mapping (Phase II). 
Gianinetto, M. (2009). Influence of the elevation accuracy in the updating of large scale geodatabases in mountain urban areas using IKONOS images. Journal of Applied Remote Sensing, 3, 033536-033536-033517.

Gleyzer, A., Denisyuk, M., Rimmer, A. \& Salingar, Y. (2004). A fast recursive GIS algorithm for computing Strahler stream order in braided and nonbraided networks. JAWRA Journal of the American Water Resources Association, 40, 937-946.

Goldman, S.J., Jackson, K. \& Bursztynsky, T.A. (1986). Erosion and sediment control handbook. McGraw Hill Book Co., New York.

Government of Rwanda (2005a). Organic Law determining the modalities of protection, conservation and promotion of environment in Rwanda, Official Gazette of the Republic of Rwanda ; Kigali August 2005.

Government of Rwanda (2005b). Organic Law determining the use and management of land in Rwanda. Official Gazette of the Republic of Rwanda 44, 20-36.

Government of Rwanda (2010a). Land Sub-sector Strategic Plan of 2009/10-2013/14; Prepared for the Land Thematic Working Group National Land Center (NLC); Ministry of Environment and Lands (MINELA), Kigali, July 2010.

Government of Rwanda (2010b). Ministerial Order $N^{\circ} 007 / 16.01$ of 15/07/2010 Determining the Length of Land on Shores of Lakes and Rivers Transferred to Public Property; Official Gazette n 37 of 13/09/2010; Kigali, July 2010.

Government of Rwanda (2010c). Ministerial Order N¹4/11.30 of 21/12/2010 Determining the Models of Land Consolidation and Its Productivity; Official Gazette n0 52 of 27/12/2010; Minister of Agriculture and Animal Resources; Kigali, December 2010.

Government of Rwanda (2011). Rwanda National Land use and Development Master Plan, Ministry of Environment and Lands (MINELA), Kigali Rwanda

Government of Rwanda (2012a). Law n ${ }^{\circ} 4 / 2012$ of 15/06/2012 relating to the planning of land use and development in Rwanda; Official Gazette $n^{\circ} 31$ of 30/07/2012; Kigali, June 2012.

Government of Rwanda (2012b). National Land use and Development Master Plan.

Government of Rwanda (2012c). Rwanda, Land Administration System Procedures Manual, Rwanda Natural Resources Authority.Lands and Mapping Department. Version v1.0 Published October, 2012.

Government of Rwanda (2013). Kigali: State of Environment and Outlook Report 2013, Rwanda Envinment Authority, Kigali 
Government of Rwanda (2015). National Informal Settlement Upgrading Strategy; Ministry of Infrastructure; Republic of Rwanda, Final Draft, Kigali Rwanda; December 2015.

Henssen, J. (1995). Basic principles of the main cadastral systems in the world. In Proceedings of the One Day Seminar held during the Annual Meeting of Commission 7, Cadastre and Rural Land Management, of the International Federation of Surveyors (FIG).

Henssen, J.L.G. \& Williamson, I.P. (1990). Land registration, cadastre and its interaction; a world perspective, Proceedings XIX FIG Congress, Commission 7, Paper 701.1, Helsinki 1990, p. 14-43.

Imwangana, F.M., Dewitte, O., Ntombi, M. \& Moeyersons, J. (2014). Topographic and road control of mega-gullies in Kinshasa (DR Congo). Geomorphology, 217, 131-139.

Ionita, I. (2006). Gully development in the Moldavian Plateaus of Romania. Elsevier, 68, 133140.

Jenson, S.K. \& Domingue, J.O. (1988). Extracting Topographic Structure from Digital Elevation Data for Geographic Information System Analysis. Photogrammetric Engineering and Remote Sensing 54, 1593-1600.

Johnston, K. \& MacCoy, J. (2001). Using ArcGIS spatial analyst. Environmental Systems Research Institute (ESRI), New York Street, Redlands.

Junior, O.C., Guimaraes, R., Freitas, L., Gomes-Loebmann, D., Gomes, R.A., Martins, E. et al. (2010). Urbanization impacts upon catchment hydrology and gully development using mutli-temporal digital elevation data analysis. Earth Surface Processes and Landforms: The Journal of the British Geomorphological Research Group, 35, 611-617.

Kabirigi, M., Mugambi, S., Musana, B.S., Ngoga, G.T., Muhutu, J.C., Rutebuka, J. et al. (2017). Estimation of soil erosion risk, its valuation and economic implications for agricultural production in western part of Rwanda.

Karamage, F., Zhang, C., Kayiranga, A., Shao, H., Fang, X., Ndayisaba, F. et al. (2016a). USLEBased Assessment of Soil Erosion by Water in the Nyabarongo River Catchment, Rwanda. International journal of environmental research and public health, 13, 835.

Karamage, F., Zhang, C., Ndayisaba, F., Shao, H., Kayiranga, A., Fang, X. et al. (2016b). Extent of cropland and related soil erosion risk in Rwanda. Sustainability, 8, 609.

Karlsson, K. \& Viklander, M. (2008). Polycyclic aromatic hydrocarbons (PAH) in water and sediment from gully pots. Water, Air, and Soil Pollution, 188, 271-282.

Kim, J.B., Saunders, P. \& Finn, J.T. (2005). Rapid assessment of soil erosion in the Rio Lempa Basin, Central America, using the universal soil loss equation and geographic information systems. Environmental Management, 36, 872-885. 
Knighton, D. (2014). Fluvial forms and processes: a new perspective. Routledge.

Lal, R. (1988). Effects of slope length, slope gradient, tillage methods and cropping systems on runoff and soil erosion on a tropical Alfisol: preliminary results. International Association for Hydrological Sciences Publication, 174, 79-88.

Manyifika, M. \& Rientjes, T. (2015). Diagnostic assessment on urban floods using satellite data and hydrologic models in Kigali, Rwanda. University of Twente Faculty of GeoInformation and Earth Observation (ITC), The Netherlands

Mark, D.M. (1988). Network Models in Geomorphology. In: Modelling Geomorphological Systems (ed. Anderson, MG). New York: John Wiley, pp. 73-97.

Martino, D. (2001). Buffer zones around protected areas: a brief literature review. Electronic Green Journal, 1.

Matthew, I. \& Aderemi, A. (2013). TS03D - The Use of Geoinformation - 6571: Relating Urban Parameters to Gully Development in Southwestern, Nigeria. FIG Working Week Environment for sustainability Abuja, Nigeria, 6-10 May 2013.

Miller, J.D., Nyhan, J.W. \& Yool, S.R. (2003). Modeling potential erosion due to the Cerro Grande Fire with a GIS-based implementation of the Revised Universal Soil Loss Equation. International Journal of Wildland Fire, 12, 85-100.

Mitchell, J., Bubenzer, G., McHenry, J. \& Ritchie, J. (1980). Soil loss estimation from fallout cesium-137 measurements. Soil loss estimation from fallout cesium-137 measurements., 393-401.

Moeyersons, J. (1988). The complex nature of creep movements on steeply sloping ground in Southern Rwanda. Earth Surface Processes and Landforms, 13, 511-524.

Moeyersons, J. (1991). Ravine formation on steep slopes: forward versus regressive erosion. Some case studies from Rwanda. Catena, 18, 309-324.

Moeyersons, J. (2003). The topographic thresholds of hillslope incisions in southwestern Rwanda. Catena, 50, 381-400.

Morgan, R.P.C. (2009). Soil erosion and conservation. John Wiley \& Sons.

Morgan, R.P.C. \& Davidson, D.A. (1991). Soil Erosion and Conservation, Longman Group, U.K.

Mugisha, F. (2015). Modelling and assessment of urban flood hazards based on end-user requirements. Kigali-Rwanda. MSc.Thessis submitted to Faculty of Geo-Information Science and Earth Observation of the University of Twente. Enschede, Netherlands, February 2015. 
Munyaneza, O., Nzeyimana, Y.K. \& Umaru, G.W. (2013). Hydraulic Structures Design for Flood Control in the Nyabugogo Wetland, Rwanda. Nile Basin Water Science \& Engineering Journal, 6.

Mureithi, I.M. (2015). Flash Flood Hazard and Coping Strategies in Urban Areas: Case Study in Mpazi Catchment, Kigali Rwanda; MSc.Thessis submitted to Faculty of Geo-Information Science and Earth Observation of the University of Twente. Enschede, Netherlands, February 2015.

Nyesheja, E.M., Chen, X., El-Tantawi, A.M., Karamage, F., Mupenzi, C. \& Nsengiyumva, J.B. (2019). Soil erosion assessment using RUSLE model in the Congo Nile Ridge region of Rwanda. Physical Geography, 40, 339-360.

Nyssen, J., Poesen, J., Moeyersons, J., Luyten, E., Veyret-Picot, M., Deckers, J. et al. (2002). Impact of road building on gully erosion risk: a case study from the northern Ethiopian highlands. Earth Surface Processes and Landforms: The Journal of the British Geomorphological Research Group, 27, 1267-1283.

O'Callaghan, J.F. \& Mark, D.M. (1984). The extraction of drainage networks from digital elevation data. Computer vision, graphics, and image processing, 28, 323-344.

Oliveira, A.H., da Silva, M.A., Silva, M.L.N., Curi, N., Neto, G.K. \& de Freitas, D.A.F. (2013). Development of topographic factor modeling for application in soil erosion models. SORIANO, MCH Soil processes and current trends in quality assessment. Rijeka: InTech, 111-138.

Onyando, J., Kisoyan, P. \& Chemelil, M. (2005). Estimation of potential soil erosion for river perkerra catchment in Kenya. Water Resources Management, 19, 133-143.

Panagos, P., Borrelli, P., Meusburger, K., Alewell, C., Lugato, E. \& Montanarella, L. (2015a). Estimating the soil erosion cover-management factor at the European scale. Land Use Policy, 48, 38-50.

Panagos, P., Borrelli, P., Meusburger, K., van der Zanden, E.H., Poesen, J. \& Alewell, C. (2015b). Modelling the effect of support practices (P-factor) on the reduction of soil erosion by water at European scale. Environmental science \& policy, 51, 23-34.

Park, S., Mitchell, J. \& Bubenzer, G. (1980). An analysis of splash erosion mechanics. An analysis of splash erosion mechanics.

Pilesjö, P. \& Hasan, A. (2014). A Triangular Form-based Multiple Flow Algorithm to Estimate Overland Flow Distribution and Accumulation on a Digital Elevation Model. Transactions in GIS, 18, 108-124.

Poesen, J., Nachtergaele, J., Verstraeten, G. \& Valentin, C. (2003). Gully erosion and environmental change: importance and research needs. . Catena, 50, 91-133. 
Poesen, J., Torri, D. \& Vanwalleghem, T. (2010). Gully erosion: procedures to adopt when modelling soil erosion in landscapes affected by gullying. John Wiley \& Sons: Chichester, UK.

Renard, K.G., Foster, G., Weesies, G.A., McCool, D.K. \& Yoder, D.C. (1997). Predicting Soil Erosion by Water: A Guide to Conservation Planning with the Revised Universal Soil Loss Equation (RUSLE). Agriculture Handbook, vol. 703. US Department of Agriculture, Washington, DC, pp. 1- 251.

Rowlands, L. (2019). Erosion and Sediment Control-WSUD During the Construction Phase of Land Development. In: Approaches to Water Sensitive Urban Design. Elsevier, pp. 163176.

Rowntree, K.M. (1982). Rainfall erosivity in Kenya - some preliminary considerations. Proceedings of the Second National Workshop on Soil and Water Conservation in Kenya, 10-13 March1982. University of Nairobi, Kenya Institute for Development Studies and Faculty of Agriculture. Nairobi.

Rugema Milindi, D. (2011). Evaluation of digital pen in data capturing for land administration purposes in Rwanda. Enschede, University of Twente Faculty of Geo-Information and Earth Observation ITC.

Seibert, J. \& McGlynn, B.L. (2007). A new triangular multiple flow direction algorithm for computing upslope areas from gridded digital elevation models. Water Resources Research, 43.

SHERIngénieurs-Conseils (2013). Consultancy Services for Development of Rwanda National Water Resources Master Plan Technical Note (I.W.R Management, Trans.): Rwanda Natural Resources Authority 2011-2013.

Strahler, A.N. (1957). Quantitative analysis of watershed geomorphology. Transactions American Geophysical Union, 38, 913-920.

Tarboton, D.G., Bras, R.L. \& Rodriguez-Iturbe, I. (1991). On the extraction of channel networks from digital elevation data. Hydrological processes, 5, 81-100.

Tsinda, A. \& Gakuba, A. (2010). Sustainable hazards mitigation in Kigali City (Rwanda). In 46th ISOCARP Congress. www. isocarp. net/Data/case_studies/1829 (Accessed 09 May, 2016).

UNEP (2011). Rwanda From Post-Conflict to Environmentally Sustainable Development, United Nations Environment Programme, Nairobi, Kenya.

Van der Kinijff, J.M., Jones, R.J.S. \& Montanarella, L. (2000). Soil erosion risk assessment in Europe. Office for official publications of the European communities. Luxembourg. 
Wells, M., Brandon, K. \& Hannah, L. (1992). Parks and people: linking protected area management with local communities. World Bank, Washington, DC.

Whalan, D.J. (1982). The Torrens System in Australia. Lawbook Company.

Wischmeier, W.H. \& Mannering, J. (1969). Relation of soil properties to its erodibility. Soil Science Society of America Journal, 33, 131-137.

Wischmeier, W.H. \& Smith, D.D. (1978). Predicting rainfall erosion losses -a guide for conservation planning. U.S. Department of Agriculture, Agriculture Handbook 537. 